\title{
Proposition 117 \\ Assessing the Effectiveness of Assistance in Capacity Development
}

In a Word Feedback is the dynamic process of presenting and disseminating information to improve performance. Feedback mechanisms are increasingly being recognized as key elements of learning before, during, and after. Assessments by executing agencies of the effectiveness of assistance in capacity development are prominent among these.

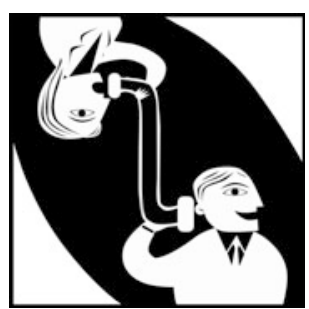

\section{Rationale}

Feedback is a circular causal process whereby some portion of a system's output is returned to the input to control the dynamic behavior of the system. In organizations, feedback is the process of sharing observations, concerns, and suggestions to improve performance. In work that seeks to address the increasingly complex challenges of development, often with limited resources, feedback is essential to maximize development impact. The Knowledge Solutions on monthly progress notes assert that the essential first steps of feedback are the processes of monitoring and evaluation. They identify challenges, recognize common constraints, and note that the submission of monthly progress notes on activities and accomplishments is too infrequently provided in the scope of projects and programs. There are 
opportunities too for more systematic capture and storage of feedback from executing agencies on the effectiveness of assistance in capacity development, prior to knowledge sharing and learning.

\section{Assessing the Effectiveness of Assistance in Capacity Development}

Capacity development is the process whereby people, organizations, and society as a whole unleash, strengthen, create, adapt, and maintain capacity over time. In 2005, the Paris Declaration on Aid Effectiveness called for capacity development to be an explicit objective of the national development and poverty reduction strategies of partner countries. Bilateral and multilateral agencies, among others, have responded by elevating capacity development in their operations, and given attention to factors that drive success and factors that deter from it.

A special evaluation study of the Independent Evaluation Department in ADB on the effectiveness of ADB's (2008) capacity development assistance classified these positive and negative factors into four categories: (i) design and quality-at-entry factors within ADB's control, (ii) design and quality-at-entry beyond ADB's control, (iii) implementation factors within ADB's control, and (iv) implementation factors beyond ADB's control. Since the success drivers in categories (i) and (iii) are design and quality-at-entry factors as well as implementation factors within ADB's control, they can be achieved through improvement in ADB's design and implementation practices for capacity development interventions. Since the success drivers in categories (ii) and (iv) are design and quality-at-entry factors as well as implementation factors beyond ADB's control, which are contextual or external level factors by nature, they tend to act as incentives (opportunities) to capacity development performance. However, the negative side of these factors will tend to act as risks or constraints (threats) to capacity development performance. The study noted that although ADB has no direct control over these risks, some of them should be identified and mitigation mechanisms formulated during the design stage with good diagnostics. In more challenging environments, it may be necessary to be more realistic by developing a phased approach to capacity development interventions, or deferring them until some of these risks are addressed.

Presumably, the findings of the study are relevant elsewhere. Further, much remains to be done to put the preconditions for such good practices in place. This does not necessarily call for reinvention of the wheel. Development agencies can, by doing less and doing it well, do better for capacity development. Simple knowledge management tools that harvest experience for subsequent sharing and use are at hand. With regard to the technical assistance modality that donors often use, that described below shows how to invites feedback on preparation, design, and implementation; the performance of consultants; the contribution to change 
management, policy development, and capacity building; and constraints to implementation.

\section{Template}

The questionnaire ${ }^{1}$ laid out below provides guidance on the preparation by executing agencies of assessments of the effectiveness of capacity development in the form of a recommended format and a description of the contents required. Naturally, flexibility in the use of the questionnaire should be exercised as it is intended to introduce approximate conformance in the more obvious components of monitoring and evaluation. The assessment, completed at the end of a technical assistance, should be submitted by the executing agency to the donor concerned, and inform both the preparation of technical assistance completion reports and the formulation of next steps.

Table. Assessing the effectiveness of assistance in capacity development: a questionnaire for executing agencies

\begin{tabular}{|c|c|c|c|c|c|}
\hline \multicolumn{6}{|c|}{ Technical Assistance Data } \\
\hline \multicolumn{6}{|c|}{ TA Title } \\
\hline \multicolumn{6}{|c|}{ TA Number } \\
\hline \multicolumn{6}{|c|}{ Executing Agency } \\
\hline \multicolumn{6}{|c|}{ TA Amount } \\
\hline \multicolumn{6}{|c|}{ Date Approved } \\
\hline \multicolumn{6}{|c|}{ TA Objective } \\
\hline \multicolumn{6}{|c|}{ Technical Assistance Preparation } \\
\hline & $\begin{array}{l}\text { How high was the TA's objective in the } \\
\text { Government's overall priorities at the } \\
\text { time, as indicated, for instance in the } \\
\text { Five-Year Development Plan at the } \\
\text { time or later? }\end{array}$ & High & Medium & Low & Do Not Know \\
\hline & $\begin{array}{l}\text { Was the TA's objective a high priority } \\
\text { of the executing agency at that time? }\end{array}$ & Yes & \multicolumn{2}{|c|}{ No } & Do Not Know \\
\hline & $\begin{array}{l}\text { Who was the principal player in } \\
\text { identifying the need for the TA? }\end{array}$ & $\mathrm{ADB}$ & Government & $\begin{array}{l}\text { Executing } \\
\text { Agency }\end{array}$ & Do Not Know \\
\hline & $\begin{array}{l}\text { How satisfactory was the process of } \\
\text { developing the terms of reference for } \\
\text { the TA in terms of adequate } \\
\text { consultation with the staff of the } \\
\text { executing agency? }\end{array}$ & $\begin{array}{c}\text { Very } \\
\text { Satisfactory }\end{array}$ & Satisfactory & $\begin{array}{c}\text { Not } \\
\text { Satisfactory }\end{array}$ & Do Not Know \\
\hline & $\begin{array}{l}\text { If not satisfactory: please cite the major } \\
\text { reasons. }\end{array}$ & & & & \\
\hline & $\begin{array}{l}\text { Was a satisfactory process for } \\
\text { institutional strengthening (i.e., }\end{array}$ & Yes & & & Do Not Know \\
\hline
\end{tabular}

\footnotetext{
${ }^{1}$ The questionnaire is adapted from ADB (1996).
} 


\begin{tabular}{|c|c|c|c|c|c|}
\hline & $\begin{array}{l}\text { enabling the executing agency itself to } \\
\text { build on the outputs of the TA) } \\
\text { developed before the TA was accepted } \\
\text { by the executing agency (e.g., starting } \\
\text { with a diagnostic analysis)? }\end{array}$ & & & & \\
\hline 6. & $\begin{array}{l}\text { Before the start of the TA, did the } \\
\text { executing agency realistically consider } \\
\text { that by the end of the TA, it would gain } \\
\text { the technical expertise to do the desired } \\
\text { work itself? }\end{array}$ & Yes & \multicolumn{2}{|c|}{ No } & Do Not Know \\
\hline 7. & $\begin{array}{l}\text { Were the major constraints, both inside } \\
\text { and outside the executing agency, } \\
\text { which could prevent the effective } \\
\text { completion of the TA satisfactorily } \\
\text { addressed prior to the terms of } \\
\text { reference being finalized? }\end{array}$ & Yes & \multicolumn{2}{|c|}{ No } & Do Not Know \\
\hline $7 \mathrm{a}$. & $\begin{array}{l}\text { If yes: please indicate whether the } \\
\text { constraints were }\end{array}$ & \multicolumn{2}{|c|}{ Internal } & \multicolumn{2}{|c|}{ External } \\
\hline \multicolumn{6}{|c|}{$\begin{array}{l}\mathrm{b} \text {. If no: please list the major constraints } \\
\text { not addressed. (See Annex for a sample } \\
\text { of constraints and problems.) }\end{array}$} \\
\hline \multicolumn{6}{|c|}{ Technical Assistance Design } \\
\hline & $\begin{array}{l}\text { How satisfactory was the design of the } \\
\text { TA to achieve its objective? }\end{array}$ & $\begin{array}{c}\text { Very } \\
\text { Satisfactory } \\
\end{array}$ & Satisfactory & $\begin{array}{c}\text { Not } \\
\text { Satisfactory }\end{array}$ & Do Not Know \\
\hline & If satisfactory: please list strengths. & \multicolumn{4}{|c|}{ If not satisfactory: please list weaknesses. } \\
\hline & $\begin{array}{l}\text { How important was the TA's objective } \\
\text { to the work of the executing agency? }\end{array}$ & $\begin{array}{c}\text { Very } \\
\text { Important }\end{array}$ & Important & $\begin{array}{l}\text { Not Very } \\
\text { Important }\end{array}$ & No Opinion \\
\hline \multicolumn{6}{|c|}{$\begin{array}{l}\text { 9a. In what way were they important? } \\
\text { - From a technical point of view } \\
\text { - From an institutional strengthening } \\
\text { point of view }\end{array}$} \\
\hline & $\begin{array}{l}\text { Did the design seek to transfer skills to } \\
\text { the executing agency by the end of the } \\
\text { TA? }\end{array}$ & Yes & \multicolumn{2}{|c|}{ No } & Do Not Know \\
\hline & $\begin{array}{l}\text { If yes: how satisfactory was the } \\
\text { approach to technology and skills } \\
\text { transfer?a }\end{array}$ & $\begin{array}{c}\text { Very } \\
\text { Satisfactory }\end{array}$ & Satisfactory & $\begin{array}{c}\text { Not } \\
\text { Satisfactory }\end{array}$ & Do Not Know \\
\hline \multicolumn{6}{|c|}{$\begin{array}{l}\text { 10b. If not satisfactory: please state in what } \\
\text { way. }\end{array}$} \\
\hline & $\begin{array}{l}\text { Did the senior management of the } \\
\text { executing agency play a major role in } \\
\text { the design of the TA? }\end{array}$ & Yes & \multicolumn{2}{|c|}{ No } & Do Not Know \\
\hline \multicolumn{6}{|c|}{$\begin{array}{ll}\text { Technical Assistance Implementation } \\
\end{array}$} \\
\hline & $\begin{array}{l}\text { Were appropriate counterpart staff } \\
\text { available to participate in the TA and } \\
\text { benefit from it? }\end{array}$ & Yes & \multicolumn{2}{|c|}{ No } & Do Not Know \\
\hline & $\begin{array}{l}\text { If yes: were the counterpart staff and } \\
\text { trainees released as required without } \\
\text { jeopardizing other high priorities of the } \\
\text { executing agency? }\end{array}$ & Yes & \multicolumn{2}{|c|}{ No } & Do Not Know \\
\hline
\end{tabular}




\begin{tabular}{|c|c|c|c|c|c|}
\hline & $\begin{array}{l}\text { When were counterpart staff made } \\
\text { available for the TA? }\end{array}$ & $\begin{array}{c}\text { From The } \\
\text { Outset }\end{array}$ & $\begin{array}{l}\text { Shortly After } \\
\text { The Beginning }\end{array}$ & $\begin{array}{l}\text { Late In The } \\
\text { Project }\end{array}$ & Not At All \\
\hline 12c. & $\begin{array}{l}\text { Was the counterpart approach to skills } \\
\text { transfer effective? }\end{array}$ & Yes & \multicolumn{2}{|c|}{ No } & Do Not Know \\
\hline \multicolumn{6}{|c|}{ 12d. If no: please cite the major reasons. } \\
\hline 13. & $\begin{array}{l}\text { Were recommendations made under } \\
\text { the TA to improve the functioning of } \\
\text { the executing agency? }\end{array}$ & Yes & \multicolumn{2}{|c|}{ No } & Do Not Know \\
\hline $13 \mathrm{a}$. & $\begin{array}{l}\text { If yes: were the recommendations } \\
\text { appropriate? }\end{array}$ & Yes & \multicolumn{2}{|c|}{ No } & Do Not Know \\
\hline $13 \mathrm{~b}$. & $\begin{array}{l}\text { If yes: were the recommendations } \\
\text { accepted? }\end{array}$ & Yes & \multicolumn{2}{|c|}{ No } & Do Not Know \\
\hline $13 \mathrm{c}$. & $\begin{array}{l}\text { If yes: how substantially were the } \\
\text { recommendations acted upon? }\end{array}$ & Significantly & \multicolumn{2}{|c|}{ Partially } & Not At All \\
\hline 14. & Did the TA do any staff training? & Yes & \multicolumn{2}{|c|}{ No } & Do Not Know \\
\hline $14 \mathrm{a}$. & $\begin{array}{l}\text { If yes: approximately how many staff } \\
\text { were planned to be trained and how } \\
\text { many were actually trained? }\end{array}$ & \multicolumn{2}{|c|}{ Planned To Be Trained } & \multicolumn{2}{|c|}{ Actually Trained } \\
\hline $14 \mathrm{~b}$. & $\begin{array}{l}\text { What level of long-term improvement } \\
\text { in staff performance did the training } \\
\text { produce? }\end{array}$ & $\begin{array}{c}\text { Marked } \\
\text { Improvement }\end{array}$ & $\begin{array}{c}\text { Some } \\
\text { Improvement }\end{array}$ & $\begin{array}{c}\text { No } \\
\text { Improvement }\end{array}$ & Do Not Know \\
\hline 15. & Were the trainers & $\begin{array}{c}\text { Very } \\
\text { Competent }\end{array}$ & Competent & $\begin{array}{l}\text { Not Very } \\
\text { Competent }\end{array}$ & Do Not Know \\
\hline 16. & Was the training & $\begin{array}{l}\text { Just Long } \\
\text { Enough }\end{array}$ & $\begin{array}{l}\text { Slightly Too } \\
\text { Short }\end{array}$ & Too Short & Do Not Know \\
\hline 17. & $\begin{array}{l}\text { At the end of the TA, how well could } \\
\text { the counterparts and trainees, without } \\
\text { further technical assistance, perform } \\
\text { the tasks they were supposed to } \\
\text { perform? }\end{array}$ & $\begin{array}{c}\text { Very } \\
\text { Satisfactory }\end{array}$ & Satisfactory & $\begin{array}{c}\text { Not } \\
\text { Satisfactory }\end{array}$ & Do Not Know \\
\hline \multicolumn{6}{|c|}{$\begin{array}{l}\text { 17a. If not satisfactory: please cite the major } \\
\text { reasons. }\end{array}$} \\
\hline 18. & $\begin{array}{l}\text { How satisfactorily was the TA's } \\
\text { objective achieved? }\end{array}$ & $\begin{array}{c}\text { Very } \\
\text { Satisfactory }\end{array}$ & Satisfactory & $\begin{array}{c}\text { Not } \\
\text { Satisfactory }\end{array}$ & Do Not Know \\
\hline $18 \mathrm{a}$. & $\begin{array}{l}\text { Please identify one significant and } \\
\text { enduring outcome directly resulting } \\
\text { from the implementation of the TA's } \\
\text { objective. }\end{array}$ & & & & \\
\hline 19. & $\begin{array}{l}\text { Did the senior management of the } \\
\text { executing agency play a major role in } \\
\text { the implementation and general } \\
\text { guidance of the TA? }\end{array}$ & Yes & \multicolumn{2}{|c|}{ No } & Do Not Know \\
\hline $19 \mathrm{a}$. & $\begin{array}{l}\text { If no: did the lack of involvement have } \\
\text { an adverse effect on the outcomes of } \\
\text { the TA? }\end{array}$ & Yes & \multicolumn{2}{|c|}{ No } & Do Not Know \\
\hline 20. & $\begin{array}{l}\text { Would the TA have been more effective } \\
\text { if staff in central agencies had been } \\
\text { more involved? }\end{array}$ & Yes & \multicolumn{2}{|c|}{ No } & Do Not Know \\
\hline \multicolumn{6}{|c|}{ 20a. If yes: please explain in what way. } \\
\hline 21. & $\begin{array}{l}\text { Did women working in the executing } \\
\text { agency benefit from the TA? }\end{array}$ & Yes & \multicolumn{2}{|c|}{ No } & Do Not Know \\
\hline
\end{tabular}




\begin{tabular}{|c|c|c|c|c|c|}
\hline 21a. & $\begin{array}{l}\text { If yes: please indicate approximately } \\
\text { how many and in what way. }\end{array}$ & & & & \\
\hline 22. & $\begin{array}{l}\text { Please list the major problems with TA } \\
\text { implementation. (See Annex for a } \\
\text { sample of constraints and problems.) }\end{array}$ & & & & \\
\hline \multicolumn{6}{|c|}{$\begin{array}{cc}\text { Performance of Consultants } \\
\end{array}$} \\
\hline 23. & $\begin{array}{l}\text { Please rate the overall performance of } \\
\text { the consultants. }\end{array}$ & $\begin{array}{c}\text { Very } \\
\text { Satisfactory } \\
\end{array}$ & Satisfactory & $\begin{array}{c}\text { Not } \\
\text { Satisfactory }\end{array}$ & Do Not Know \\
\hline $23 a$. & In terms of technical competence. & $\begin{array}{c}\text { Very } \\
\text { Satisfactory }\end{array}$ & Satisfactory & $\begin{array}{c}\text { Not } \\
\text { Satisfactory }\end{array}$ & Do Not Know \\
\hline $23 \mathrm{~b}$. & In terms of training and skills transfer. & $\begin{array}{c}\text { Very } \\
\text { Satisfactory } \\
\end{array}$ & Satisfactory & $\begin{array}{c}\text { Not } \\
\text { Satisfactory } \\
\end{array}$ & Do Not Know \\
\hline 24. & $\begin{array}{l}\text { How well did the consultants } \\
\text { understand the needs of the executing } \\
\text { agency? }\end{array}$ & $\begin{array}{c}\text { Very } \\
\text { Satisfactory }\end{array}$ & Satisfactory & $\begin{array}{c}\text { Not } \\
\text { Satisfactory }\end{array}$ & Do Not Know \\
\hline 25. & $\begin{array}{l}\text { Please rate how well the consultants } \\
\text { adapted their technical competencies to } \\
\text { the needs and competencies of the } \\
\text { executing agency. }\end{array}$ & $\begin{array}{c}\text { Very } \\
\text { Satisfactory }\end{array}$ & Satisfactory & $\begin{array}{c}\text { Not } \\
\text { Satisfactory }\end{array}$ & Do Not Know \\
\hline 26. & $\begin{array}{l}\text { How culturally sensitive was the work } \\
\text { of the consultants? }\end{array}$ & $\begin{array}{c}\text { Very } \\
\text { Satisfactory }\end{array}$ & Satisfactory & $\begin{array}{c}\text { Not } \\
\text { Satisfactory }\end{array}$ & Do Not Know \\
\hline 27. & $\begin{array}{l}\text { How well did the consultants } \\
\text { understand the professional needs of } \\
\text { the people working in the executing } \\
\text { agency? }\end{array}$ & $\begin{array}{c}\text { Very } \\
\text { Satisfactory }\end{array}$ & Satisfactory & $\begin{array}{c}\text { Not } \\
\text { Satisfactory }\end{array}$ & Do Not Know \\
\hline 28. & $\begin{array}{l}\text { Did the consultants pay any special } \\
\text { attention to the needs of the women } \\
\text { working in the executing agency? }\end{array}$ & Yes & \multicolumn{2}{|c|}{ No } & Do Not Know \\
\hline 29. & Did the consultants & $\begin{array}{l}\text { Help The } \\
\text { Executing } \\
\text { Agency To Do } \\
\text { Things }\end{array}$ & \multicolumn{2}{|c|}{ Do Things For The Agency } & Do Not Know \\
\hline & $\begin{array}{l}\text { Would you employ the consultants } \\
\text { again? }\end{array}$ & Yes & \multicolumn{2}{|c|}{ No } & Do Not Know \\
\hline \multicolumn{6}{|c|}{ 30a. If no: please explain why. } \\
\hline \multicolumn{6}{|c|}{ Institutional Development } \\
\hline 31. & $\begin{array}{l}\text { Please rate the contribution of the TA } \\
\text { in the improvement of the following: }\end{array}$ & Major & Minor & None At All & Do Not Know \\
\hline $31 \mathrm{a}$. & $\begin{array}{l}\text { Management competencies of the } \\
\text { executing agency (i.e., is the executing } \\
\text { agency better managed as a result of } \\
\text { the TA?). }\end{array}$ & Major & Minor & None At All & Do Not Know \\
\hline $31 \mathrm{~b}$. & Policy capacity of the executing agency. & Major & Minor & None At All & Do Not Know \\
\hline 31c. & $\begin{array}{l}\text { Operating systems of the executing } \\
\text { agency (i.e., did the TA improve } \\
\text { budget, planning, information systems, } \\
\text { and procedures on a sustainable } \\
\text { basis?). }\end{array}$ & Major & Minor & None At All & Do Not Know \\
\hline $31 \mathrm{~d}$. & $\begin{array}{l}\text { Organizational efficiency of the } \\
\text { executing agency (i.e., has productivity } \\
\text { of the executing agency increased as a } \\
\text { direct result of the TA?). }\end{array}$ & Major & Minor & None At All & Do Not Know \\
\hline
\end{tabular}




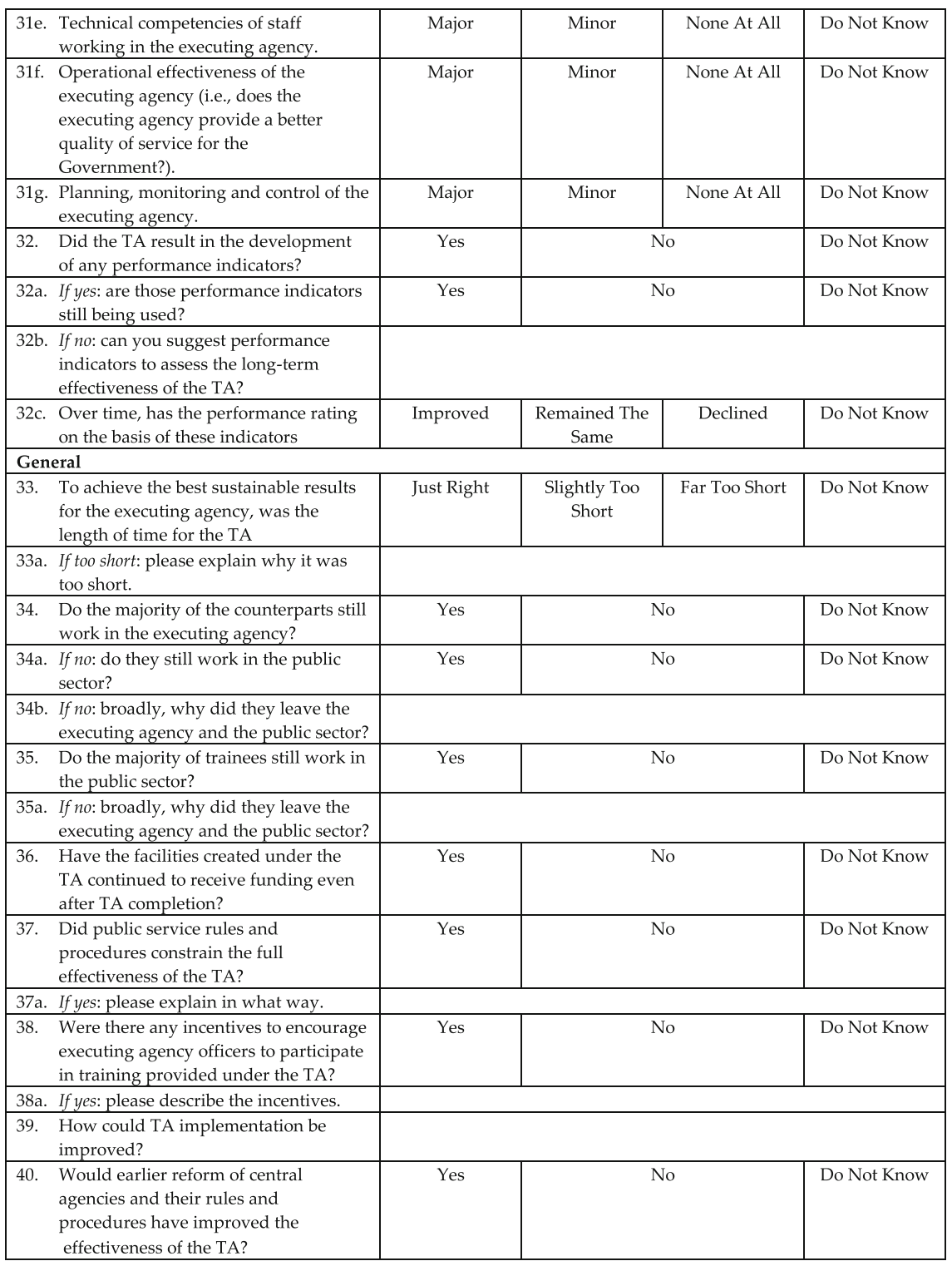




\begin{tabular}{|c|c|c|c|c|c|}
\hline \multicolumn{6}{|c|}{ 40a. If yes: please explain in what way. } \\
\hline & $\begin{array}{l}\text { Have the benefits of the TA been } \\
\text { sustainable? }\end{array}$ & Yes & \multicolumn{2}{|c|}{ No } & Do Not Know \\
\hline \multicolumn{6}{|c|}{ 41a. If no: please cite the major reasons. } \\
\hline 42. & $\begin{array}{l}\text { Please rate the performance of the ADB } \\
\text { in TA preparation, administration, and } \\
\text { supervision. }\end{array}$ & $\begin{array}{c}\text { Very } \\
\text { Satisfactory }\end{array}$ & Satisfactory & $\begin{array}{c}\text { Not } \\
\text { Satisfactory }\end{array}$ & Do Not Know \\
\hline \multicolumn{6}{|c|}{$\begin{array}{l}\text { 42a. If not satisfactory: please explain in what } \\
\text { way. }\end{array}$} \\
\hline $42 \mathrm{~b}$. & $\begin{array}{l}\text { Please rate the ADB's responsiveness } \\
\text { and flexibility. }\end{array}$ & $\begin{array}{c}\text { Very } \\
\text { Satisfactory }\end{array}$ & Satisfactory & $\begin{array}{c}\text { Not } \\
\text { Satisfactory }\end{array}$ & Do Not Know \\
\hline \multicolumn{6}{|c|}{$\begin{array}{l}\text { 42c. If not satisfactory: please explain in what } \\
\text { way. }\end{array}$} \\
\hline 43. & $\begin{array}{l}\text { In retrospect, please rate the long-term } \\
\text { effectiveness of the TA on the executing } \\
\text { agency. }\end{array}$ & Successful & $\begin{array}{c}\text { Partly } \\
\text { Successful }\end{array}$ & Unsuccessful & Do Not Know \\
\hline \multicolumn{6}{|c|}{ Annex: Sample of Constraints and Problems in Implementation } \\
\hline & & \multicolumn{2}{|c|}{ Question $7 \mathrm{~b}$} & \multicolumn{2}{|c|}{ Question 22} \\
\hline \multicolumn{6}{|c|}{$\begin{array}{l}\text { 1. Shortage of counterpart staff and } \\
\text { trainees/staff had no time. }\end{array}$} \\
\hline \multicolumn{6}{|c|}{$\begin{array}{l}\text { 2. Lack of managerial skills/inadequate } \\
\text { technical know-how. }\end{array}$} \\
\hline \multicolumn{6}{|c|}{$\begin{array}{l}\text { 3. Management/financial/organizational } \\
\text { problems within the executing agency } \\
\text { and within the Government itself. }\end{array}$} \\
\hline \multicolumn{6}{|c|}{$\begin{array}{l}\text { 4. Sociopolitical/cultural/geographic and } \\
\text { demographic factors. }\end{array}$} \\
\hline \multicolumn{6}{|c|}{$\begin{array}{ll}\text { 5. Unclear or absent } \\
\text { policy/legislation/guidelines/control } \\
\text { mechanisms. }\end{array}$} \\
\hline \multicolumn{6}{|c|}{$\begin{array}{l}\text { 6. Inadequate database/inaccurate data } \\
\text { generated/ineffective or poor } \\
\text { management information system. }\end{array}$} \\
\hline \multicolumn{6}{|c|}{$\begin{array}{l}\text { 7. Lack of incentives, support services, } \\
\text { infrastructure, and facilities. }\end{array}$} \\
\hline \multicolumn{6}{|c|}{$\begin{array}{ll}\text { 8. } & \text { Lack of } \\
\text { coordination/communication/overlappi } \\
\text { ng functions/disputes among } \\
\text { concerned implementing agencies/task } \\
\text { network. }\end{array}$} \\
\hline \multicolumn{6}{|c|}{$\begin{array}{l}\text { 9. Lack of capital/funds/delay in release } \\
\text { of Government counterpart funds. }\end{array}$} \\
\hline \multicolumn{6}{|c|}{$\begin{array}{l}\text { 10. Delay in recruitment of } \\
\text { consultants/poor performance of } \\
\text { consultants }\end{array}$} \\
\hline \multicolumn{6}{|c|}{ 11. Training } \\
\hline \multicolumn{6}{|c|}{ 11a. Was too difficult or too short. } \\
\hline \multicolumn{6}{|c|}{$\begin{array}{l}\text { 11b. Was not relevant to work/did not } \\
\text { provide skills usable in the prevailing } \\
\text { circumstances. }\end{array}$} \\
\hline & $\begin{array}{l}\text { Did not interest the trainees/did not } \\
\text { offer incentives. }\end{array}$ & & & & \\
\hline
\end{tabular}

\section{Source Author}

${ }^{\mathrm{a}}$ Refers to transfer of technology and skills to counterparts and to the executing agency as distinct from trainees

'Staff nominated to facilitate the consultants' work and sometimes assist it. Counterparts are not trainees 


\section{References}

ADB (1996) Special study on assessment of the effectiveness of bank technical assistance for capacity building in Indonesia. Manila

ADB (2008) Special evaluation study on effectiveness of ADB's capacity development assistance: how to get institutions right. Manila

The opinions expressed in this chapter are those of the author(s) and do not necessarily reflect the views of the Asian Development Bank, its Board of Directors, or the countries they represent.

Open Access This chapter is licensed under the terms of the Creative Commons Attribution-NonCommercial 3.0 IGO license (http://creativecommons.org/licenses/by-nc/3.0/igo/) which permits any noncommercial use, sharing, adaptation, distribution and reproduction in any medium or format, as long as you give appropriate credit to the Asian Development Bank, provide a link to the Creative Commons license and indicate if changes were made.

Any dispute related to the use of the works of the Asian Development Bank that cannot be settled amicably shall be submitted to arbitration pursuant to the UNCITRAL rules. The use of the Asian Development Bank's name for any purpose other than for attribution, and the use of the Asian Development Bank's logo, shall be subject to a separate written license agreement between the Asian Development Bank and the user and is not authorized as part of this CC-IGO license. Note that the link provided above includes additional terms and conditions of the license.

The images or other third party material in this chapter are included in the chapter's Creative Commons license, unless indicated otherwise in a credit line to the material. If material is not included in the chapter's Creative Commons license and your intended use is not permitted by statutory regulation or exceeds the permitted use, you will need to obtain permission directly from the copyright holder.

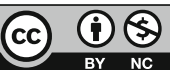

